This is the post-print version of a book chapter. Please cite this publication as follows:

Lambrechts, W. and Ceulemans, K. (2013). Sustainability Assessment in Higher Education. Evaluating the Use of the Auditing Instrument for Sustainability in Higher Education (AISHE) in Belgium. In: Caeiro, S., Leal Filho, W., Jabbour, C., Azeiteiro, U. (Eds.). Sustainability Assessment Tools in Higher Education Institutions. Mapping Trends and Good Practice Around the World. Springer, pp. 157-174.

Weblink to the publication: http://www.springer.com/gp/book/9783319023748

\title{
Sustainability Assessment in Higher Education: Evaluating the Use of the Auditing Instrument for Sustainability in Higher Education (AISHE) in Belgium
}

Wim Lambrechts a and Kim Ceulemans ${ }^{b}$

${ }^{a}$ KHLeuven - Leuven University College, Department of Business Studies (ECHO)

Hertogstraat 178, B-3001 Leuven, Belgium

E-mail:wim.lambrechts@khleuven.be

Tel. 0032 (0)475 709743

${ }^{b}$ KU Leuven - University of Leuven, Centre for Economics and Corporate Sustainability

Warmoesberg 26, B-1000 Brussels, Belgium

E-mail:kim.ceulemans@hubrussel.be

Tel. 0032 (0)2 6098277

Keywords: sustainability assessment, AISHE instrument, sustainability in higher education

ABSTRACT Assessing the integration of sustainability in higher education can be a powerful lever for organisational change in higher education institutions. When comparing the available tools and instruments for assessment of sustainability in higher education, the Auditing Instrument for Sustainability in Higher Education (AISHE) has proven to be a reliable tool, providing a qualitative approach to sustainability assessment. This article presents the AISHE tool and discusses its use in two higher education institutions in Belgium. Included in this work is an analysis of the audits in several study programs, and an 
independent evaluation of the instrument based on literature and Belgian good practices.

The experiences of the Belgian institutions with sustainability assessment tools can motivate other higher education institutions around the world to start up sustainability assessment in their institution.

\section{Introduction}

Since the 1990s, many higher education institutions (HEIs) worldwide signed sustainability charters and declarations - of which the Copernicus Charter (1994) is one of the most cited-thus accepting an active role in promoting sustainable lifestyles (Lozano et al. 2013; Wright 2004). Throughout the years, the societal appeal to contribute to the transition process towards sustainability became more urgent, and HEls were blamed for responding too slowly to this appeal. An analysis of 11 main declarations, charters, and partnerships for higher education by Lozano et al. (2013) pointed out that the majority of them addressed initiatives for the integration of sustainable development (SD) in higher education in all four major functions of HEls -i.e., education, research, community outreach, and university operation, as defined by Cortese (2003). Nevertheless, this does not imply nor insure that the signatories actually integrate SD in their institutions (Lozano et al. 2013).

Although many examples exist of concrete actions for SD integration within the four functions of HEls, ranging from the development of SD courses, teacher trainings on SD, or student competency schemes for SD —all of them being "curriculum" initiatives— to typical "operations" initiatives, e.g. energy and waste management programs or staff/student diversity policies, it is clear that the integration of sustainability in higher education still deals with a broad range of fundamental barriers (Ceulemans et al. 2011a; Lozano 2006a; Thomas 2004; Velazquez et al. 2006), preventing or holding HEls back from implementing sustainability initiatives in their institution. These barriers are, amongst others, related to the lack of awareness among university leaders, teachers and researchers, the disciplinary structure of higher education, and the lack of funding. Furthermore, there is a conceptual problem we have to deal with: SD is often perceived as a vague and complex concept, thus making it difficult to implement and integrate in specific courses (Lambrechts et al. 2008, 2009). Finally, the lack of suitable indicators and instruments to monitor and assess the efforts undertaken by HEls complicates the assessment process, resulting in the lack of a clear view on the current situation of sustainability integration in higher education worldwide (Lambrechts et al. 2009; Lozano et al. 2013).

Many tools for SD management, assessment, and reporting have been developed throughout the years-e.g., Sustainability Balanced Scorecard (Figge et al. 2002), Global 
Reporting Initiative (GRI) guidelines (GRI 2011), ISO 14000 Series (ISO 2004), ISO 26000 (ISO 2012). However, most of these tools are defined on a general level, and are not (fully) suitable to use in the context of HEls, as there are hardly any specific indicators for education, research, and outreach within these existing tools (Lozano 2006b). Specific instruments have also been developed for the analysis of SD in the core activities of higher education, and some of them have been reviewed in the past (Cole 2003; Glasser and Nixon 2002; Glover et al. 2011; Lozano 2006b; Shriberg 2002, 2004; Siemer et al. 2006). Focused on the validity and comparability of results, some of these tests and reviews concluded with a demand for the development of a more comprehensive tool, addressing some of the downsides and limitations of the use of the current assessment tools (Ceulemans et al. 2011a; Glover et al. 2011). Furthermore, the reviews have limited attention towards empirical data on the practical use of SD assessment instruments in HEls, the perspective of audit participants and the possibilities for organisational change and development (Lambrechts et al. 2009).

Looking at the reviews found in the literature, the Auditing Instrument for Sustainability in Higher Education (AISHE) was evaluated as an innovative European example (Shriberg 2004; Siemer et al. 2006), and it continues to be applied in more and more institutions (Glover et al. 2011). This paper tackles the need for empirical data on SD assessment instruments in HEIs, and therefore discusses the experiences with the AISHE instrument in two Belgian HEls. The research presents the results of the assessments in various study programs of these institutions, and focuses on the evaluation of the AISHE instrument and its assessment process. The structure of the chapter is as follows: section 2 covers the main reasons for SD assessment in higher education, while in section 3 the materials and methods of the chapter are presented. Section 4 provides the results of AISHE auditing in two Belgian HEls. Section 5 provides an in-depth discussion on the evaluation of the instrument. The chapter ends with general conclusions in section 6.

\section{Reasons to Assess Sustainability in Higher Education}

Although SD assessment tools can be powerful levers for organisational change in higher education, little research has been done to investigate the current situation of sustainability integration in HEls (Ceulemans et al. 2011a; Desha et al. 2009; Lambrechts et al. 2013; Shriberg 2002). SD assessment in higher education can be performed for various reasons, which can be clustered in three core groups: (1) policy development, (2) mainstreaming sustainable higher education, and (3) transparency and communication (Ceulemans et al. 2011a; Lambrechts et al. 2008; Roorda 2007; Shriberg 2004).

A first reason for SD assessment in higher education is policy development. Since the beginning of the 1990s, various HEls around the world signed a number of charters and 
declarations, specifically fostering the integration of sustainability in higher education (Lozano et al. 2013). However, the integration of SD in higher education is a slow process. Many projects were launched, focusing on education, competences, curriculum, research, outreach, assessment, reporting and training, but a thorough and structured approach seems to be missing (Lambrechts et al. 2013; Lozano et al. 2013). Assessment instruments for SD could guide a translation from the theoretical charters and declarations to a practical approach in HEIs. Moreover, these instruments identify strengths and weaknesses, provide policy makers with qualitative and quantitative information about the integration process, and suggest priorities for future policy (Roorda 2007; Shriberg 2004). Additionally, using assessment instruments could lead to the integration of SD in the general quality management system of the HEI (Roorda 2010).

Secondly, the assessment of SD integration in higher education could lead to the mainstreaming of sustainability in the institution. Management and staff are often unaware of the sustainability projects and efforts in their institution. Although Ceulemans et al. (2011a) stress that "a combined top-down/bottom-up approach seems to be the most beneficial for sustained sustainability integration efforts", the use of sustainability assessment instruments is clearly a top and middle management affair. Nevertheless, assessment on the organisational scale could also raise awareness and create a sense of responsibility among all internal stakeholders, i.e. management, staff, and students (Siemer et al. 2006), and thereby facilitate mainstreaming of sustainability in the institution.

A third group of reasons to assess SD in higher education are more communicative reasons. Assessment instruments provide the management with clear data, useful to report about the efforts of their HEI to integrate SD. In (larger) companies, an annual sustainability report has become a way to communicate to all stakeholders, and creates awareness and trust among various stakeholders. However, in higher education, SD reporting is not widely spread (Lozano et al. 2013; Roorda 2010). The assessment of SD in higher education could be an incentive for the management, because it can lead to a special certificate, and provides opportunities to compare their results, benchmark their efforts and learn from each other (Shriberg 2004).

\section{Materials and Methods}

A number of tools and instruments have been developed or modified to help assess SD in HEls. Siemer et al. (2006) note that worldwide more than 220 projects for assessing SD integration are present, most of which originated in America and England, and sometimes presenting specific guidelines and tools. Without giving a comprehensive overview, some examples are given to express the variety of the available tools: AISHE (Roorda 2001), the 
Graphical Assessment for Sustainability in Universities (GASU) tool, combining some of the GRI indicators with additional indicators for the core business of HEls (Lozano 2006b), the Sustainability Tool for Assessing UNiversities' Curricula Holistically (STAUNCH) (Lozano 2010), the Sustainability Tracking, Assessment and Rating System (STARS) (AASHE 2012), the revised version AISHE 2.0 (Roorda et al. 2009), and Waheed et al.'s (2011) uncertaintybased DPSEEA-Sustainability index Model (uD-SiM).

Shriberg (2002 and 2004) compared existing assessment instruments for SD in higher education, and concluded that most of the tools did not provide mechanisms for comparing campus efforts against other institutions, and that the reasons for undertaking the SD initiatives were often neglected in these tools. Despite the number of available tools and instruments, Velazquez et al. (2006) still report the lack of effective indicators and call for the development of a control instrument as a major priority for HEls.

Within the reviews of the tools and instruments, AISHE is often seen as a good example of a process-oriented approach (Shriberg 2004), and because of the innovative nature and methodology (Siemer et al. 2006). Given these strengths of the instrument, and the structure based on a quality management model (Roorda 2001) were the reasons for two Belgian HEls to start using AISHE within their study programs. This section presents the AISHE instrument, with a focus on the structure, criteria and assessment process.

\subsection{The AISHE Instrument}

AISHE is an instrument designed to assess the level of integration of sustainability in HEls. The instrument can be downloaded for free and is available in Dutch, English and Swedish. AISHE is based on a model for quality management developed by the European Foundation for Quality Management (EFQM), enhanced by the Dutch Institute for Quality Management (INK) for commercial use in companies, and consequently adapted by a higher education expert group on quality management for application in HEls (Roorda 2002). The EFQM-INK model starts from the idea that, based on a set of criteria, an organisation is situated in a certain development stage: (1) activity oriented, (2) process oriented, (3) system oriented, (4) chain oriented or (5) society oriented. The stages of AISHE are cumulative, and the institution moves towards a holistic integration, striving to achieve the status of "sustainable higher education". AISHE consists of twenty criteria defined and structured using the Deming-cycle of Plan-Do-Check-Act.

The criteria of AISHE are formulated according to three fundamental principles: they are process oriented (rather than content oriented); qualitative, presented on an ordinal scale (rather than quantitative); and descriptive (rather than prescriptive) (Roorda 2001). Table 1 provides an overview of the twenty criteria of AISHE 1.2. Each criterion is described 
thoroughly in the AISHE manual, with short characteristic descriptions for each of the five stages (Roorda 2001).

Table 1. The Criteria of AISHE 1.2 (Roorda 2001) and Scores for Different Certificate Levels (Roorda and Martens 2008)

\begin{tabular}{|c|c|c|c|c|c|c|}
\hline & & Certificate Level (\# stars) & 1 & 2 & 3 & 4 \\
\hline \multirow[t]{10}{*}{ Plan } & \multicolumn{2}{|c|}{ 1. Vision and Policy } & & & & \\
\hline & 1.1 & Vision & 1 & 2 & 3 & 4 \\
\hline & 1.2 & Policy & 1 & 2 & 3 & 4 \\
\hline & 1.3 & Communication & 1 & 2 & 3 & 4 \\
\hline & 1.4 & Internal environmental management & 1 & 2 & 3 & 4 \\
\hline & \multicolumn{2}{|c|}{ 2. Expertise } & & & & \\
\hline & 2.1 & Network & - & 1 & 2 & 3 \\
\hline & 2.2 & Expert group & - & 1 & 2 & 3 \\
\hline & 2.3 & Staff development plan & 1 & 2 & 3 & 4 \\
\hline & 2.4 & Research and external services & - & - & 1 & 2 \\
\hline \multirow[t]{10}{*}{ Do } & \multicolumn{2}{|c|}{ 3. Educational Goals and Methodology } & & & & \\
\hline & 3.1 & Profile of the graduate & 1 & 2 & 3 & 4 \\
\hline & 3.2 & Educational methodology & 1 & 2 & 3 & 4 \\
\hline & 3.3 & Role of the teacher & - & 1 & 2 & 3 \\
\hline & 3.4 & Student examination & 1 & 2 & 3 & 4 \\
\hline & \multicolumn{2}{|c|}{ 4. Educational Context } & & & & \\
\hline & 4.1 & Curriculum & 1 & 2 & 3 & 4 \\
\hline & 4.2 & Integrated problem handling & 1 & 2 & 3 & 4 \\
\hline & 4.3 & Traineeship, graduation & 1 & - & 3 & 4 \\
\hline & 4.4 & Speciality & - & 2 & 1 & 2 \\
\hline \multirow[t]{5}{*}{ Check } & \multicolumn{2}{|c|}{ 5. Result Assessment } & & & & \\
\hline & 5.1 & Staff & - & 1 & 2 & 3 \\
\hline & 5.2 & Students & - & 1 & 2 & 3 \\
\hline & 5.3 & Professional field & - & 1 & 2 & 3 \\
\hline & 5.4 & Society & - & 1 & 2 & 3 \\
\hline
\end{tabular}

The AISHE instrument is developed to be used on the level of a single education program, or -in case of several comparable programs within one university - on the level of a faculty or department. Although AISHE includes some criteria assessing sustainability integration on the institutional level-mainly within the "vision and policy" subset-it is impossible to conduct an AISHE audit for a university as a whole (Roorda 2007). An AISHE audit gathers a group of 15-20 stakeholders from the university: one or more manager(s), several lecturers, some other staff members, some students and if possible some external stakeholders. Each participant has to be in some way involved in the specific education program that is being assessed. After an introduction to the topic of sustainability and to the auditing instrument, each participant individually reads the criteria and decides-to his or her personal opinionwhich stage seems the most appropriate for every single criterion. After that, the stakeholders participate in a consensus meeting, where the results are presented and 
discussed. Each criterion is discussed in this meeting, and consensus has to be reached about the stage in which the criterion is situated. It is important to mention that the arguments used in the consensus discussion to choose the current phase of the criterion must be verifiable, meaning that each argument can be proven out by evidence or documents if asked for. Preferably, for each criterion, a desired situation is also described. For a detailed description of the different steps within AISHE, we refer to the AISHE manual (Roorda 2001).

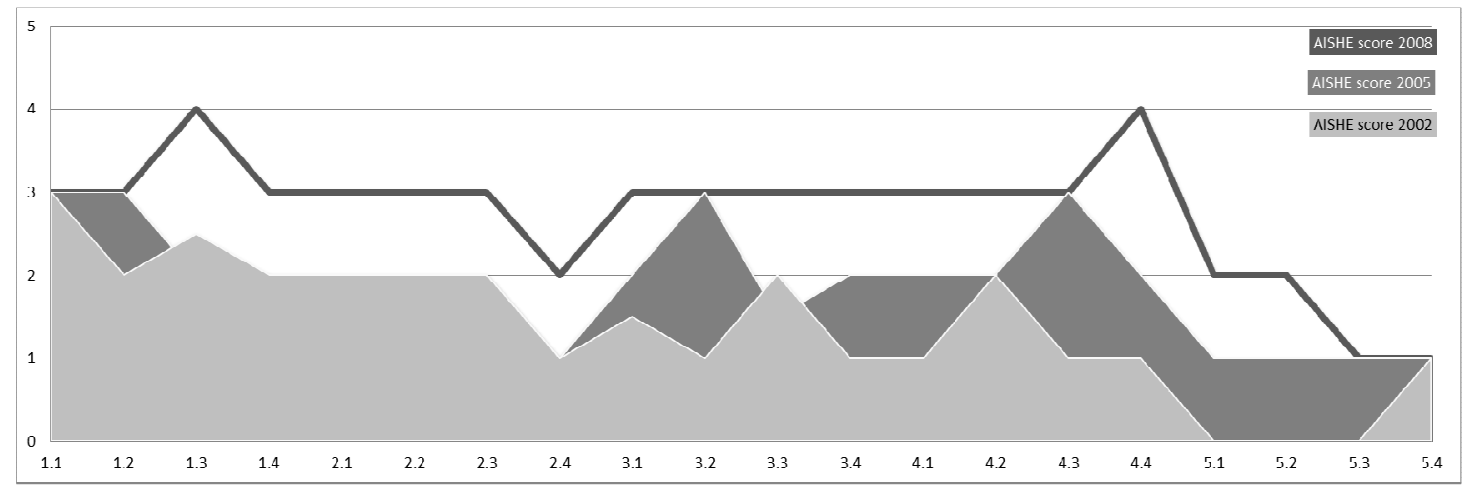

Fig. 1. Results of the AISHE Audits in Fontys University (Source: based on Roorda 2010: 147)

The outcome of the audit is a written report and a diagram, showing the results, desired situation and priorities. When the AISHE audit is led by an official AISHE auditor, the education program can afterwards request a certificate issued by the Dutch Committee. In the Netherlands, several universities (mainly universities of applied science) have used AISHE and received a certificate. Certificates can be issued on four levels (ranging from one star to four stars), depending of the extent of SD integration in the education program, e.g. for a one star certificate, a study program needs to reach level 1 for 11 criteria, as shown in Table 1. Also, some HEls performed several subsequent audits in time. Figure 1 shows the result of three subsequent AISHE-audits in Fontys University in The Netherlands, as reported by Roorda (2010).

\subsection{Methods}

The use of AISHE in several Belgian study programs has led to a considerable output of data, both on the results and outcomes of these assessments, as on the practical experiences within the HEls in undergoing the assessment process. The evaluation of the instrument can be broken down into the following questions:

1. What are the results of the use of AISHE in various study programs?

2. What are the experiences of participants regarding the assessment process? 
3. What are the strengths and weaknesses of the instrument?

The information provided in the results and discussion section is based on several data sources:

- Literature study on previous reports on the validity of the instrument;

- The reports on the results of the various assessments in the study programs in both HEls (as shown in Table 2);

- The internal reports on the use of AISHE in both HEls;

- Two focus groups organised by both HEls, with 30 participants from a variety of internal and external stakeholders (in November 2008 and March 2011).

\section{Results}

In Belgium, two HEls have officially used AISHE with the guidance of an AISHE auditor, while some other universities also used it without guidance of an external auditor (i.e. a selfevaluation). Both Leuven University College (KHLeuven) and Hogeschool-Universiteit Brussel (HUB) have done several AISHE audits in the past years, resulting in one star and two star certificates for several study programs.

The initial driver for KHLeuven to start with the AISHE audits was the start of a research project on sustainability integration in higher education, which provided funding to prepare and perform the audits in all study programs. Another internal driver was the interest of individual staff members and policy development within the organisation (Verhulst and Lambrechts 2013). KHLeuven received the one star certificate for all its study programs, ranging from business management, teacher training, health care, technology, and social work, based on the AISHE audits between 2003 and 2006. In 2010, KHLeuven obtained a two star certificate for its study programs in business management (Ceulemans et al. 2011b). For HUB, policy development was the main driver to start with AISHE audits. In 2005, there was a growing interest within HUB to take up a more systemic approach towards SD integration. HUB's Faculty of Economics and Management decided to start using AISHE as a tool for continuous improvement of SD efforts within one academic program, and to consequently use these audit results to guide further SD integration within the organisation. HUB achieved a two star certificate for its Environment, Health and Safety Management Master Program in 2006, while in 2010 this certificate was renewed for another three year period. Simultaneously, the Master in Business Engineering received the two star certificate after being subjected to its first AISHE audit in 2010. An overview of the audits in both institutions can be found in Table 2. The results of the 11 audits in KHLeuven and 4 audits in HUB are shown in Table 3. 
Table 2 AISHE Audits in KHLeuven and HUB

\begin{tabular}{|c|c|c|c|c|}
\hline KHLeuven & Date & Department & Study Program(s) & Type \\
\hline A & $\begin{array}{l}\text { September } \\
2003\end{array}$ & Business Studies & $\begin{array}{l}\text { Business Management } \\
\text { Office Management }\end{array}$ & External \\
\hline$B$ & $\begin{array}{l}\text { September } \\
2004\end{array}$ & Business Studies & $\begin{array}{l}\text { Business Management } \\
\text { Office Management }\end{array}$ & External \\
\hline C & October 2005 & $\begin{array}{l}\text { Teacher Education } \\
\text { (Campus Leuven) }\end{array}$ & Secondary Education & External \\
\hline $\mathrm{D}$ & October 2005 & Social Work & Social Work & External \\
\hline$E$ & October 2005 & Health and Technology & $\begin{array}{l}\text { Nursing } \\
\text { Midwifery }\end{array}$ & External \\
\hline $\mathrm{F}$ & October 2005 & Health and Technology & $\begin{array}{l}\text { Chemistry } \\
\text { Biomedical Laboratory Technology } \\
\text { Nutrition and Dietetics }\end{array}$ & External \\
\hline $\bar{G}$ & December 2005 & $\begin{array}{l}\text { Teacher Education } \\
\text { (Campus Leuven) }\end{array}$ & $\begin{array}{l}\text { Pre-primary Education } \\
\text { Primary Education }\end{array}$ & External \\
\hline $\mathrm{H}$ & February 2006 & Health and Technology & $\begin{array}{l}\text { Medical Management Assistant } \\
\text { Applied Information Technology }\end{array}$ & External \\
\hline I & December 2006 & $\begin{array}{l}\text { Teacher Education } \\
\text { (Campus Diest) }\end{array}$ & $\begin{array}{l}\text { Pre-primary Education } \\
\text { Primary Education }\end{array}$ & External \\
\hline $\mathrm{J}$ & March 2009 & Business Studies & $\begin{array}{l}\text { Business Management } \\
\text { Office Management }\end{array}$ & $\begin{array}{l}\text { Self- } \\
\text { evaluation }\end{array}$ \\
\hline $\mathrm{K}$ & March 2010 & Business Studies & $\begin{array}{l}\text { Business Management } \\
\text { Office Management }\end{array}$ & External \\
\hline HUB & Date & Faculty & Study program(s) & Type \\
\hline $\mathrm{L}$ & November 2005 & $\begin{array}{l}\text { Economics and } \\
\text { Management }\end{array}$ & $\begin{array}{l}\text { Bachelor/Master Environment, } \\
\text { Health and Safety Management }\end{array}$ & $\begin{array}{l}\text { Self- } \\
\text { evaluation }\end{array}$ \\
\hline M & August 2006 & $\begin{array}{l}\text { Economics and } \\
\text { Management }\end{array}$ & $\begin{array}{l}\text { Business Management } \\
\text { Office Management }\end{array}$ & External \\
\hline $\mathrm{N}$ & March 2010 & $\begin{array}{l}\text { Economics and } \\
\text { Management }\end{array}$ & $\begin{array}{l}\text { Bachelor/Master Environment, } \\
\text { Health and Safety Management }\end{array}$ & External \\
\hline $\mathrm{O}$ & March 2010 & $\begin{array}{l}\text { Economics and } \\
\text { Management }\end{array}$ & $\begin{array}{l}\text { Bachelor/Master Business } \\
\text { Engineering }\end{array}$ & External \\
\hline
\end{tabular}


Table 3. Overview of the Results of the AISHE Audits in KHLeuven and HUB (Based on: Lambrechts et al. 2009 and internal AISHE reports)

\begin{tabular}{|c|c|c|c|c|c|c|c|c|c|c|c|c|c|c|c|c|c|}
\hline \multicolumn{3}{|l|}{ Criterion } & \multicolumn{11}{|c|}{ KHLeuven } & \multicolumn{4}{|c|}{ HUB } \\
\hline & & & \multirow{2}{*}{$\begin{array}{c}\mathbf{A} \\
1\end{array}$} & \multirow{2}{*}{$\begin{array}{l}\text { B } \\
3\end{array}$} & \multirow{2}{*}{$\begin{array}{l}\mathbf{C} \\
2\end{array}$} & \multirow{2}{*}{$\begin{array}{l}\mathbf{D} \\
1\end{array}$} & \multirow{2}{*}{\begin{tabular}{c|}
$\mathbf{E}$ \\
$1 / 2$
\end{tabular}} & \multirow{2}{*}{$\begin{array}{l}\mathbf{F} \\
1\end{array}$} & \multirow{2}{*}{$\begin{array}{c}\mathbf{G} \\
0\end{array}$} & \multirow{2}{*}{\begin{tabular}{c|}
$\mathbf{H}$ \\
$1 / 2$ \\
\end{tabular}} & \multirow{2}{*}{$\begin{array}{c}\mathbf{I} \\
2 / 3 \\
\end{array}$} & \multirow{2}{*}{$\begin{array}{l} \\
3\end{array}$} & \multirow{2}{*}{$\begin{array}{c}\mathbf{K} \\
3 / 4\end{array}$} & \multirow{2}{*}{$\begin{array}{l}\mathbf{L} \\
1\end{array}$} & \multirow{2}{*}{$\begin{array}{c}\mathbf{M} \\
3\end{array}$} & \multirow{2}{*}{$\frac{\mathbf{N}}{3 / 4}$} & \multirow{2}{*}{$\begin{array}{c}\mathbf{0} \\
3 / 4\end{array}$} \\
\hline 1. Vision and & 1.1. & Vision & & & & & & & & & & & & & & & \\
\hline policy & 1.2. & Policy & 2 & 3 & 2 & 1 & $1 / 2$ & 1 & 0 & $1 / 2$ & 2 & 3 & $3 / 4$ & 1 & 3 & $3 / 4$ & $3 / 4$ \\
\hline & 1.3. & Communication & 1 & 2 & 1 & 1 & 1 & 1 & 1 & 1 & 2 & 3 & $4 / 5$ & 1 & 3 & $2 / 3$ & $2 / 3$ \\
\hline & 1.4. & Internal environmental management & 1 & 1 & 1 & 1 & $1 / 2$ & 2 & 1 & $1 / 2$ & $3 / 4$ & 2 & $2 / 3$ & 1 & 2 & $2 / 3$ & $2 / 3$ \\
\hline \multirow[t]{4}{*}{ 2. Expertise } & 2.1. & Network & $1 / 2$ & 2 & 1 & 2 & 2 & $1 / 2$ & 1 & 0 & 2 & 2 & $4 / 5$ & 1 & 3 & 4 & 4 \\
\hline & 2.2. & Expert group & $1 / 2$ & $2 / 3$ & 2 & 2 & 1 & 1 & 1 & 1 & 3 & 3 & $3 / 4$ & 3 & 4 & 4 & 4 \\
\hline & 2.3. & Staff development plan & 1 & 2 & 1 & 1 & $1 / 2$ & 1 & 1 & 1 & $1 / 2$ & 2 & 3 & 1 & $3 / 4$ & 3 & 3 \\
\hline & 2.4 & Research and external services & 1 & 2 & 1 & 1 & 1 & 1 & 1 & 1 & 2 & 4 & 4 & 1 & $3 / 4$ & 3 & 3 \\
\hline \multirow{4}{*}{$\begin{array}{l}\text { 3. Educational } \\
\text { goals and } \\
\text { methodology }\end{array}$} & 3.1. & Profile of the graduate & 1 & $2 / 3$ & 1 & 1 & $1 / 2$ & $1 / 2$ & 1 & 1 & 1 & $3 / 4$ & $3 / 4$ & 2 & 4 & 4 & 4 \\
\hline & 3.2. & Educational methodology & 2 & 2 & 3 & 3 & 4 & 3 & 3 & 3 & 3 & $3 / 4$ & 3 & 3 & 3 & 4 & 3 \\
\hline & 3.3. & Role of the teacher & 1 & $1 / 2$ & 1 & 1 & 1 & 1 & 1 & 1 & 2 & 3 & $3 / 4$ & 1 & 2 & $1 / 2$ & $1 / 2$ \\
\hline & 3.4. & Student examination & 1 & 1 & 1 & 1 & $1 / 2$ & 1 & 1 & 1 & 1 & 2 & $2 / 3$ & 1 & $2 / 3$ & 3 & 3 \\
\hline \multirow{4}{*}{$\begin{array}{l}\text { 4. Educational } \\
\text { context }\end{array}$} & 4.1. & Curriculum & 1 & $1 / 2$ & 1 & 1 & 1 & 1 & 1 & 1 & 1 & 2 & $2 / 3$ & 2 & $3 / 4$ & 4 & $2 / 3$ \\
\hline & 4.2 & Integrated problem handling & 1 & 2 & 2 & 2 & 3 & $1 / 2$ & $2 / 3$ & $2 / 3$ & 3 & 3 & 3 & 4 & 3 & 3 & 3 \\
\hline & 4.3. & Traineeship, graduation & 1 & 2 & 2 & 1 & 1 & 1 & 1 & $1 / 2$ & $2 / 3$ & 3 & 3 & 3 & 3 & 5 & $4 / 5$ \\
\hline & 4.4. & Speciality & 0 & 0 & 0 & 0 & 0 & $0 / 2$ & 1 & 0 & $1 / 2$ & 2 & $2 / 3$ & 4 & 3 & 3 & 2 \\
\hline \multirow{4}{*}{$\begin{array}{l}\text { 5. Result } \\
\text { assessment }\end{array}$} & 5.1. & Staff & 0 & 0 & 0 & 0 & 0 & 0 & 0 & 1 & 1 & 2 & 3 & 0 & 1 & 1 & 1 \\
\hline & 5.2. & Students & 0 & 0 & 0 & 0 & 0 & 0 & 0 & 1 & 1 & 2 & 3 & 0 & 1 & 1 & 1 \\
\hline & 5.3. & Professional field & 1 & 1 & 0 & 0 & 0 & 0 & 0 & 0 & 0 & 1 & 3 & 0 & 1 & 1 & 1 \\
\hline & 5.4. & Society & 0 & 0 & 0 & 0 & 0 & 0 & 0 & 0 & 1 & 1 & 2 & 0 & 1 & 1 & 1 \\
\hline
\end{tabular}


Moreover, both KHLeuven and HUB performed some subsequent AISHE audits. The results of these subsequent audits are interesting to analyse, in order to find out if and to what extent the SD integration is actually improving throughout the years. Figure 2 shows the results of the four AISHE audits within the Bachelor program in Business Management at KHLeuven. Figure 3 shows the results of HUB's subsequent AISHE audits for the Bachelor/Master in Environment, Health and Safety Management. Both graphs show an overall improvement of SD integration in the study programs throughout the years.

Nevertheless, the level of some criteria can also decrease from one audit to the next, the result and achieved level for a certain criterion does not assure that this level can be attained in later stages without particular attention. Also, results show that participants are actually grading the criteria lower in self-evaluation (without guidance of an auditor, KHLeuven, 2009 and HUB, 2005) than in the following audits with an external auditor.

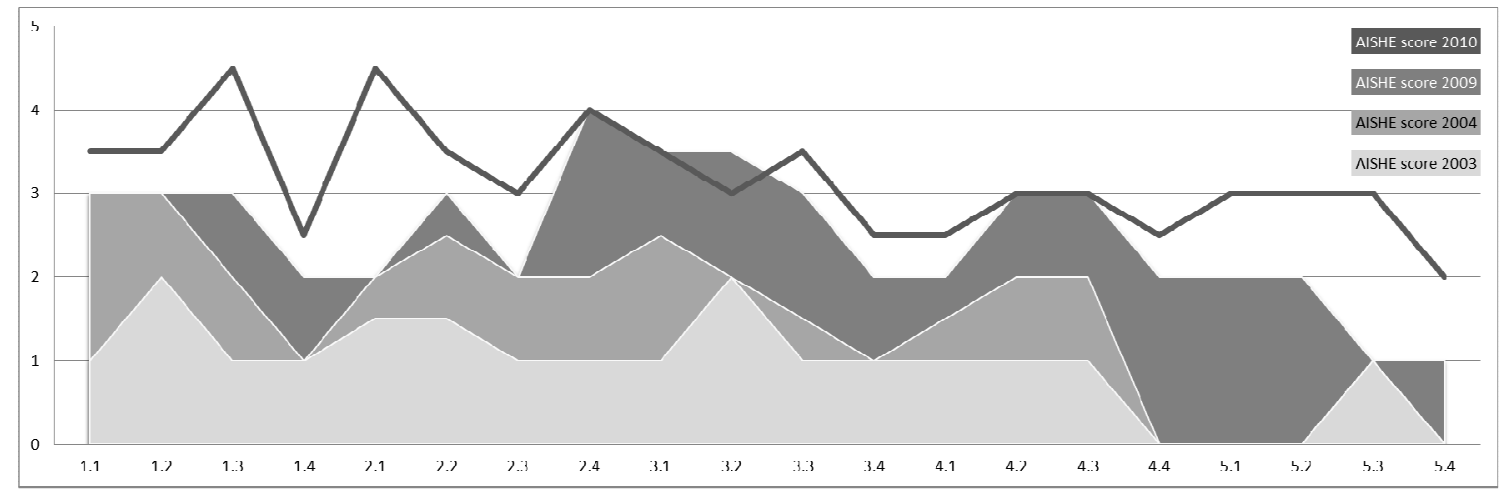

Fig. 2. Results of the AISHE Audits in KHLeuven, Bachelor Business Management (based on Lambrechts et al. 2009, Ceulemans et al. 2011b)

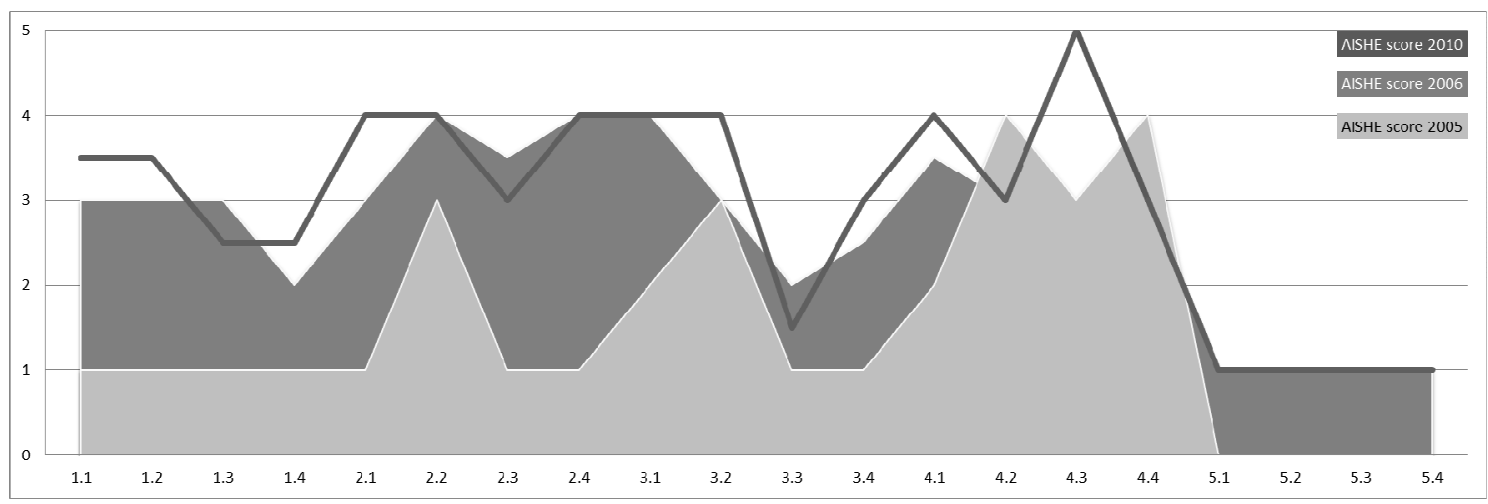

Fig. 3. Results of the AISHE Audits in HUB, Bachelor/Master Environment, Health and Safety Management (based on Ceulemans et al. 2011b and internal audit reports) 


\section{Discussion: Evaluation of AISHE}

The use of AISHE was evaluated based on the audit experiences of KHLeuven and HUB (as shown in sect. 1.3), on information gathered from the literature (as shown in sect. 1.2 and 1.3), and from two focus groups with internal and external stakeholders. Both focus groups were organised by KHLeuven and HUB, in collaboration with the Flemish government, Department of Environment, Nature and Energy. Thirty stakeholders who participated at the focus groups represented other Flemish HEls (teachers, students, policy makers), governmental organisations, civil society organisations and NGO's. The first focus group (November 2008) discussed three issues: (1) results of an assessment for organisational development, (2) creating awareness for SD, (3) SD certification and accreditation. The second focus group (March 2011) focused on the results of the recent AISHE audits in KHLeuven and HUB, and discussed strengths, weaknesses and possibilities for organisational development.

Based on the literature, the AISHE reports of KHLeuven and HUB, and the outcomes of the focus groups, Table 4 shows an analysis of the strengths, weaknesses, opportunities and threats of the AISHE instrument, regarding (1) the structure of AISHE, (2) the process of the audits and (3) the results of the audits.

\subsection{Structure of AISHE}

Regarding the structure of AISHE, one of the main strengths seems to be the quality management approach, offering a structural framework for the entity initiating the auditing process. The evaluation pointed out that the EFQM model provides a good methodological basis for the tool and offers opportunities to connect with quality management of a study program. Defining the criteria according to the Deming cycle of "Plan-Do-Check-Act" gives the instrument a clear structure. AISHE's format ensures the continued work on integrating $\mathrm{SD}$, but allows for flexibility of the methods or of the criteria to focus on for a certain period. This flexibility is actually also a downside of the instrument, because the quality circle is not closed. Continual improvement is possible when the achievement of desired outcomes and priorities of a previous audit would be assessed within the subsequent audit. Without this connection between two audits, or conditionality attached to the criteria, HEls are being admitted to lag behind on certain criteria, depending on their choice or preference at a certain moment. 
Table 4. SWOT Analysis of AISHE 1.2

\begin{tabular}{|c|c|c|c|c|}
\hline & Strengths & Weaknesses & Opportunities & Threats \\
\hline Structure & $\begin{array}{ll}\text { - } & \text { EFQM } \\
\text { - } & \text { Process oriented } \\
\text { - } & \text { Flexible framework to } \\
& \text { use on an institutional } \\
& \text { level }\end{array}$ & $\begin{array}{l}\text { - High level of complexity } \\
\text { and abstraction } \\
\text { - } \quad \text { Focus on single study } \\
\text { programs } \\
\text { - Operations, research } \\
\text { and outreach are } \\
\text { underexposed }\end{array}$ & $\begin{array}{l}\text { - } \text { Add elements of } \\
\text { operations, research, } \\
\text { outreach } \\
\text { - } \quad \text { Modular system } \\
\text { - Link with quality system }\end{array}$ & $\begin{array}{l}\text { - } \text { Complexity of the } \\
\text { instrument } \\
\text { - } \text { Risk of fragmentation in } \\
\text { modular structure } \\
\text { - Difficult to compare } \\
\text { between programs / } \\
\text { institutions }\end{array}$ \\
\hline Process & $\begin{array}{ll}\text { - } & \text { Interactive } \\
\text { - } & \text { Involvement of different } \\
\text { stakeholders } \\
\text { - } \\
\text { Raise awareness, "aha- } \\
\text { erlebnis" } \\
\text { - Formulate desired } \\
\text { situation }\end{array}$ & $\begin{array}{ll}\text { - } & \text { Only usable in small } \\
\text { groups } \\
\text { - } \\
\text { Motivation not always } \\
\text { included } \\
\text { - Emphasis on } \\
\text { - } \quad \text { "Light-initiatives" are not } \\
\text { included }\end{array}$ & $\begin{array}{l}\text { Enlarge scale (to be } \\
\text { used with a larger group } \\
\text { of participants) } \\
\text { - Present the concept of } \\
\text { an audit in a clear way to } \\
\text { prevent difficulties in the } \\
\text { consensus meeting }\end{array}$ & $\begin{array}{l}\text { Might become too time } \\
\text { consuming } \\
\text { - Risk of wrong } \\
\text { interpretation of criteria } \\
\text { - Might become too } \\
\text { complex for participants }\end{array}$ \\
\hline Results & 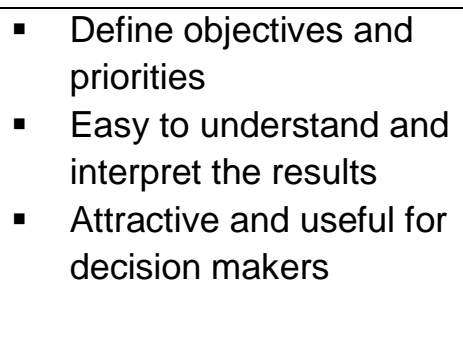 & 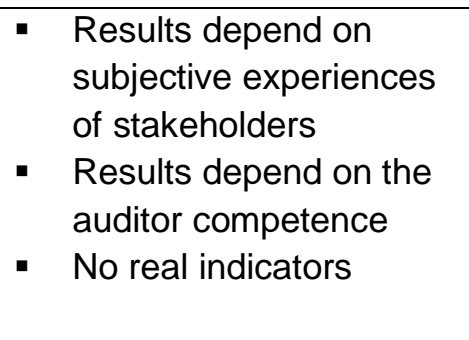 & $\begin{array}{l}\text { - Offers opportunities for } \\
\text { capacity building } \\
\text { - } \text { Define (quantitative) } \\
\text { indicators } \\
\text { - Possibilities for } \\
\text { accreditation and } \\
\text { benchmarking }\end{array}$ & 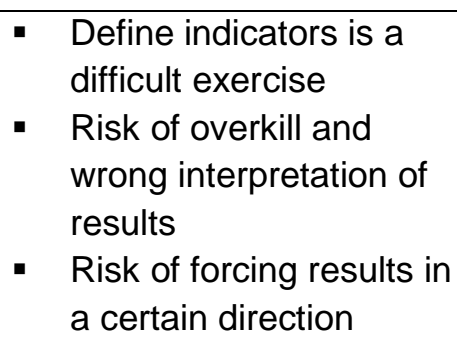 \\
\hline
\end{tabular}


The AISHE tool is intended to be used to assess the integration of SD into specific study programs. On the one hand, this is a weakness of the instrument, since one and the same $\mathrm{HEI}$ can be a SD integration leader for a certain educational program, while completely ignoring SD issues within the curriculum of another program. On the other hand, this could also be seen in a more positive way: AISHE's flexibility allows for the discussion of sustainability integration to begin in one place within an institution and then grow outward.

Nevertheless, an important weakness is that it does not provide any guarantees for extension to other programs or faculties. It might also be the case that implementation in a single study program does not offer any incentive for other programs to integrate SD issues. Whether or not the study programs are in a way related, by mutual lecturers or mutual research topics, or interest of management staff in further integrating might be determining for the levering capacity of AISHE when only initially applied in one program of the institution.

However, even though the AISHE method can only be applied to a selected study program, some criteria force an evaluation of the performance of the entire institution. Criteria such as vision, policy, and environmental management are usually established on an institutional level. Therefore, even though one study program may excel in integrating SD in curriculum, if the institution is not taking steps to ensure the sustainability of operations, it is not possible to achieve a high AISHE rating. Nevertheless, stakeholders often state that certain aspects of SD integration on the institutional level (e.g. operations, research) are underexposed in the instrument.

\subsection{Process of AISHE}

In the literature, AISHE is often seen as "an excellent example of a process-oriented approach to sustainability assessment" (Shriberg 2004). Furthermore, the experiences of both KHLeuven and HUB, and feedback gathered during the focus groups, showed that regarding the process, awareness-raising seems to be a clearly positive consequence of AISHE. An audit invokes involvement, and broadens the reach of active people within the organization, since different types of stakeholders are actively involved. The process of the audit is evaluated very positively, especially the interactivity, dialogue and consensus meeting. Taking part in an audit starts an awareness-raising process with the participants, because (1) SD is a new concept for them and/or (2) they were not aware of certain sustainability initiatives in their study program. This calls for a thorough introduction into SD on the one hand, and a good communication and recognition of sustainability initiatives on the other hand.

It is very important for all participants to be on the same level when it comes to the definition of $\mathrm{SD}$, in order to avoid different interpretations and discussions during the consensus 
meeting of the audit. Therefore, special attention should be given towards the scope and questions in the instrument: sometimes they appear to be too vague, leading to very broad interpretations and confusion between different participants.

Regarding the role of participants in the audit, students provide valuable input for the audit: often they have a strong vision and come up with arguments to demonstrate their opinions. However, for some of the criteria in the instrument they do not feel confident, e.g. for the criterion "staff development plan". A possible weakness of the instrument's process is that the quality of the audit depends largely of the auditor, who has to be an expert both in the field of sustainable higher education and of the particular study program that is performing the audit.

\subsection{Results of an audit}

Regarding the results of the audits, a major strength is that the reports and graphs are attractive, useful and easy to understand and interpret. The translation into concrete actions is also considered to be a valuable outcome of the consensus meeting, which can be used to further integrate SD in the study program. Furthermore, a very positive result of the audits is that it tends to create a new dynamic in the study program, giving formerly isolated initiatives the opportunity to become more known and even widespread within the study program or university.

Moreover, there are a lot of initiatives within the courses and departments that highlight a particular aspect of SD (e.g. social initiatives), and thus contribute to a further integration of (aspects of) SD. These so-called "light" initiatives are often excluded because they do not embrace the three "P's"-i.e. people, planet, and profit—of sustainability. On the other hand, internal environmental care is considered as an example of SD. It is important to pay attention to these aspects, in order to prevent for this change of scope to create confusion and to bias the results of the audit. Another key point, emerging in all audits, is the strong emphasis on communication aspects. Not only is communication a criterion on its own in the instrument, in the other criteria communication aspects are also largely emphasized.

Although this is a particularly important factor, it may cause bias in the results of an audit.

Considerable attention needs to be paid towards the objectives aiming to achieve a certain level or "star" in the audit. If not properly introduced to the policy level, aiming for a star might be a barrier to achieving certain criteria, perceived as valuable for SD integration in general, but not crucial for the achievement of a star. These criteria might be neglected in the results and following actions, because they do not contribute to achieving the desired star level. 


\section{Conclusion}

When comparing the available tools and instruments for assessment of sustainability in higher education, AISHE 1.2 has proven to be a reliable tool, providing a qualitative approach to sustainability assessment. Nevertheless, the AISHE tool has certain strengths as well as weaknesses, emerging from its use, assessment, and evaluation within several (research) projects. The description, practical experiences and evaluation of the tool might stimulate other HEls to start using SD assessment tools within their institution, and could indicate whether the use of AISHE and its qualitative approach would be an added value for a particular educational program.

Regarding the structure of the instrument, a major strength is that the instrument is based on the EFQM model, thus providing opportunities to connect with quality management in universities. Also, the fact that the instrument is process oriented is seen as a strength. Regarding the auditing process, a positive element is the involvement of different (internal and external) stakeholders, and the fact that it raises awareness among the participants, providing a real aha-erlebnis, or eye-opener for those who are not familiar with the concept of sustainable higher education. Major strengths regarding the results are the ease in understanding and interpreting of the results, as well as the definition of a desired situation, towards which the involved stakeholders can strive in the next period.

On the other hand, the instrument has some shortcomings. Research, community outreach and operations are underexposed in the AISHE tool, although equally important roles of HEIs as education. The instrument can only be used in small groups on the level of single study programs, and the results may be biased by the subjective experiences of participants or the auditor's competences.

The use and evaluation of AISHE version 1.2 has led to the development of new versions of the instrument, i.e. AISHE 2.0 (Roorda et al. 2009), AISHE 2012 (Hobéon 2012a), and ARISE (Hobéon 2012b). AISHE 2.0 was developed by an international expert group (Roorda et al. 2009). It is a modular tool, applying the same approach as AISHE 1.2, and working with a set of different criteria, but focusing in a more balanced way on each of the four roles of a university: education, research, outreach and operations. In order to achieve a holistic view, a fifth module was developed, i.e. the identity module (Roorda et al. 2009), covering vision and policy criteria at the level of the institution. AISHE 2012 and ARISE were developed in 2012 by the Dutch consultancy firm Hobéon, with the cooperation of a Dutch-Belgian expert team. AISHE 2012 (Hobéon 2012a) is also based on the AISHE 1.2 tool, but the criteria and the approach have been revised and are more adapted to current tendencies in the higher education sector. Besides the AISHE 2012 instrument, Hobéon also developed a new instrument, called "Assessing Responsibility In Sustainable Education", or ARISE (Hobéon 
$2012 b)$. This instrument is based on the ISO 26000 principles, and mainly covers organisational aspects (the "operational side" of HEIs), or focuses on the HEl's corporate social responsibility.

The use and evaluation of these newly developed instruments in the near future should be encouraged, since this will indicate whether these instruments can counter some of the described weaknesses of the original AISHE instrument, and whether they are able to take into account some of its opportunities and threats and therefore offer a clear added value to their predecessor, AISHE 1.2.

\section{References}

Ceulemans, K., De Prins, M., Cappuyns, V. \& De Coninck, W. (2011a). Integration of sustainable development in higher education's curricula of applied economics : Large-scale assessments, integration strategies and barriers. Journal of Management \& Organization, 17(5), 621-640.

Ceulemans, K., Lambrechts, W. \& Vervrangen, A. (2011b). Duurzaamheidsaudits in het hoger onderwijs. Do's en dont's op basis van het AISHE-instrument [Sustainability assessment in higher education. Do's and dont's based on AISHE]. Interactive session, Brussels, 1 March 2011.

Cole, L. (2003). Assessing sustainability on Canadian university campuses: development of a campus sustainability assessment framework. Master thesis Environment and Management, Royal Roads University.

Cortese, A.D. (2003). The critical role of higher education in creating a sustainable future, Planning for Higher Education, 31 (3), 15-22.

CRE-COPERNICUS (1994). Copernicus Charter: The University Charter of Sustainable Development of the Conference of European Rectors (CRE), Genève.

Desha, C.J., Hargroves, K. \& Smith, M.H. (2009). Addressing the time lag dilemma in curriculum renewal towards engineering education for sustainable development. International Journal of Sustainability in Higher Education, 10 (2), 184-199.

Figge, F., Hahn, T., Schaltegger, S. \& Wagner, M. (2002). The Sustainability Balanced Scorecard - Linking Sustainability Management to Business Strategy. Business Strategy and the Environment, 11, 269-284.

Glasser, H. \& Nixon, A. (2002). Operations: From the State of the World to the State of the Academy: Campus Sustainability Assessment - A Bright Star on the Horizon. The Declaration, 6 (1). Available via ULSF. http://www.ulsf.org/pub declaration opsvol61.htm. Accessed 10 April 2013.

Glover, A., Peters, C. \& Haslett, S.K. (2011). Education for sustainable development and global citizenship: An evaluation of the validity of the STAUNCH auditing tool. International Journal of Sustainability in Higher Education, 12 (2): 125-144.

Global Reporting Initiative (2011). Sustainability Reporting Guidelines. Version 3.1. Global Reporting Initiative, Amsterdam, The Netherlands. Available via GRI. https://www.globalreporting.org/resourcelibrary/G3.1-Guidelines-Incl-Technical-Protocol.pdf Accessed 10 April 2013. 
Hobéon (2012a). Thema's: Maatschappelijk verantwoord organiseren: Keurmerk Duurzaam Hoger Onderwijs. [Themes: Corporate Social Responsibility: Certificate Sustainable Higher Education] Available via Hobéon.

http://www.hobeon.nl/thema s/mvo/keurmerk duurzaam hoger onderwijs Accessed 21 May 2013.

Hobéon (2012b). Thema's: Maatschappelijk verantwoord organiseren: Organisatietoets MVO. [Themes: Corporate Social Responsibility: Organisational assessment CSR]. Available via Hobéon. http://www.hobeon.nl/thema s/mvo/organisatietoets mvo Accessed 21 May 2013.

ISO (2004). ISO 14001: 2004. International standard: environmental management systems requirements with guidance for use. Geneva, Switzerland: International Organization for Standardization.

ISO (2010). ISO 26000: 2010. International standard: guidance on social responsibility. Geneva, Switzerland: International Organization for Standardization.

Lambrechts, W., Van den Haute, H. \& Vanhoren, I. (2008). Making progress towards sustainable higher education, design of an implementation model with guiding principles (pp. 12-15). Paper presented at Businet Annual Conference 2008 (Palma de Majorca).

Lambrechts, W. \& De Prins, M. (2008). Hogescholen en universiteiten: sterren in duurzaam hoger onderwijs. Meetinstrument duurzame ontwikkeling in hoger onderwijs [University colleges and universities: stars in sustainable higher education. Assessment instrument for sustainable development in higher education]. Interactive session, Brussels, 7 November 2008.

Lambrechts, W., Van den Haute, H. \& Vanhoren, I. (2009). Duurzaam hoger onderwijs. Appel voor verantwoord onderrichten, onderzoeken en ondernemen [Sustainable higher education. Appeal for responsible education, research and operations]. LannooCampus, Leuven.

Lambrechts, W., Mulà, I., Ceulemans, K., Molderez, I. \& Gaeremynck, V. (2013). The integration of competences for sustainable development in higher education: an analysis of bachelor programs in management. Journal of Cleaner Production, vol. 48 (June 2013), 6573.

Lozano, R. (2006a). Incorporation and institutionalization of SD into universities: breaking through barriers to change, Journal of Cleaner Production, 14, 787-796.

Lozano, R. (2006b). A tool for a Graphical Assessment of Sustainability in Universities (GASU), Journal of Cleaner Production 14, 963-972.

Lozano, R. (2010). Diffusion of sustainable development in universities' curricula: An empirical example from Cardiff University. Journal of Cleaner Production, 18: 637-644.

Lozano, R., Lukman, R., Lozano, F. J., Huisingh, D. \& Lambrechts, W. (2013). Declarations for sustainability in higher education: becoming better leaders, through addressing the university system. Journal of Cleaner Production, vol. 48 (June 2013), 10-19.

Roorda, N. (2001). Auditing Instrument for Sustainability in Higher Education. English Handbook. DHO Nederland, Amsterdam, available online: http://www.dho.nl/aishe.

Roorda, N. (2002). Assessment and Policy Development of Sustainability in Higher Education with AISHE. In Filho, W.L (ed.). Teaching Sustainability at Universities: towards curriculum greening, Environmental education, communication and sustainability. Frankfurt: Peter Lang.

Roorda, N. (2007). Project AISHE 2.0 Start document. Available via CRISTAL Grundtvig Learning Partnership. http://cristalgrundtvig.files.worldpress.com/2011/10/project-aishe-startdocument.pdf. Accessed 10 April 2013. 
Roorda, N. (2010). Sailing on the winds of change. The Odyssey to Sustainability of the Universities of Applied Sciences in the Netherlands. Ph.D. dissertation, Maastricht University.

Roorda, N. and Martens, P. (2008). Assessment and certification of higher education for sustainable development. Sustainability: The Journal of Record, 1 (1), 41-56.

Roorda, N., Rammel, C., Waara, S. \& Fra Paleo, U. (2009). Assessment Instrument for Sustainability in Higher Education. (edn. 2) Tilburg.

Siemer, S., Elmer, S. \& Rammel, C. (2006). Pilot study: Indicators of an education for sustainable development. Vienna: FORUM Umweltbildung.

Shriberg, M (2002). Institutional assessment tools for sustainability in higher education. International Journal of Sustainability in Higher Education, 3(3), 254-270.

Shriberg, M. (2004). Assessing sustainability: criteria, tools and implications. In: Corcoran, P.B. en Wals, A. (eds) Higher education and the challenge of sustainability. Problematics, Promise and Practice. Kluwer Academic Publishers, Dordrecht, p 71-86.

Thomas, I. (2004). Sustainability in tertiary curricula: what is stopping it happening? International Journal of Sustainability in Higher Education, 5(1), 33-47.

Velazquez, L., Munguia, N., Platt, A. \& Taddei, J. (2006). Sustainable university: what can be matter?, Journal of Cleaner Production, 14, 810-819.

Verhulst, E. \& Lambrechts, W. (2013). Fostering the incorporation of SD into the university system. Lessons learned from a change management perspective. Paper presented at ERSCP-EMSU Conference, Istanbul, Turkey, 4-7 June 2013.

Waheed, B., Khan, F.I., Veitch, B. \& Hawbolt, K. (2011). Uncertainty-based quantitative assessment of sustainability for higher education. Journal of Cleaner Production, 19: 720732.

Wright, T. (2004). The evolution of sustainability declarations in higher education, in: Corcoran, P.B. en Wals, A. Higher education and the challenge of sustainability.

Problematics, Promise and Practice. Kluwer Academic Publishers, Dordrecht, p 7-20.

\section{BioNotes}

Wim Lambrechts does research on all aspects of the integration of sustainable development in higher education. Since 2007, he has supervised projects in KHLeuven and HUB (currently part of KU Leuven), focusing on (education for) sustainable development in higher education, competences for sustainable development, learning and teaching methods, curriculum design, sustainability criteria and indicators, assessment instruments and policy development.

Kim Ceulemans has been working at HUB (currently part of KU Leuven) as a member of the Centre for Economics and Corporate Sustainability Research Group (CEDON) since 2006, and has been involved in different projects on education for sustainable development. She was the Faculty of Economics \& Management's sustainability coordinator, and coordinated amongst others the AISHE sustainability audits at HUB. Currently, she is working as a PhD researcher on the topic of sustainability reporting for higher education. 